\title{
Soil microbiology
}

\section{Bacillus megaterium 501 rif INTRODUCED INTO THE SOIL: FACTORS AFFECTING THE RATE OF SURVIVAL, SPORULATION AND DECOMPOSITION OF THE HERBICIDE PROMETRYN}

\author{
YU.V. KRUGLOV, T.O. LISINA
}

All-Russian Research Institute of Agricultural Microbiology, Russian Academy of Agricultural Sciences, 3, sh. Podbelskogo, St. Petersburg, 196608 Russia, e-mail yuvkruglov@yandex.ru, lisina-to@yandex.ru Supported by Russian Scientific Foundation, project № 14-26-000-94 Received April 24, 2014

\section{Abstract}

Introduction of microorganisms into the soil is a fundamental problem in application of microbial preparations in agriculture, crop production and ecology. Its effectiveness depends on many factors (i.e. the type and strain of microorganism, the physical and chemical properties of the soil, plant cover, climate and so on), which are not well understood, leading to a high variability of the results of application of microbial preparations. In this article, there is reported the first investigation of survival and sporulation dynamics of Bacillus megaterium 501 $1^{\text {rif }}$ introduced into sodpodzolic soil, depending on the temperature of the soil, organic matter content and herbicide prometryn, the 2-methylthio-4,6-bis (iso-propylamino)-sim-triazine, application. In laboratory experiments it was found that the optimal conditions for the B. megaterium $501^{\text {rif }}$ introduced into the soil are achieved at a temperature of $20^{\circ} \mathrm{C}$. After the third day after inoculation the titer of bacteria in the soil increased almost 10 times and remained at that level until the end of the experiment (32 days). B. megaterium $501^{\text {rif }}$ throughout the experiment was mainly in the form of a physiologically active cells and fits well into the soil microbiom. Under these conditions an additional incorporation into the soil of the organic matter, such as cereal straw and corn flour, leads to 10-100-fold increase of the amount of $B$. megaterium $501^{\text {rif. }}$. At $37^{\circ} \mathrm{C}$ the total number of B. megaterium $501^{\text {rif }}$ reduced several times, and stabilized at this level until the end of the experiment. In this case, $100 \%$ of $B$. megaterium $501^{\text {rif }}$ revert into spores and are physiologically inactive. The temperature below the minimum for physiological reproduction of $B$. megaterium $\left(4{ }^{\circ} \mathrm{C}\right)$ inhibits spore formation and leads to a rapid loss of physiologically active bacterial cells introduced into the soil. The total number of bacteria decreases 1000 times within a month. These data lead to the conclusion that the «low-temperature shock» reduces the competitiveness of B. megaterium to the indigenous microflora and its resistance to bactericidal metabolic products of soil biome. It is shown that at the optimum temperature $\left(20^{\circ} \mathrm{C}\right)$ of soil the $B$. megaterium inoculation and the use of additional organic matter such as straw accelerate the decomposition of herbicide prometryn, can potentially be used in a biotechnology of remediation of the soil, contaminated by herbicide.

Keywords: Bacillus megaterium, sporulation, introduction, soil, temperature, organic matter, prometryn herbicide.

Bacterial preparations are used in agriculture to stimulate plant growth and development, to protect plant against phytopathogens and pests, and as well for cleaning the soil from xenobiotics (1-4). Aerobic sporulating bacteria of the genus Bacillus, i.e. B. thuringiensis $(5,6)$, B. subtilis (7), B. megaterium (8-10) are widely applied as they are well manufacturable, long stored and suitable for use in the field. However, the efficiency of these preparations varies in a wide range due to poor knowledge of the behavior of the bacilli introduced into the soil.

Spore forming bacteria are common inhabitants in different soils. Their number depends on the soil and climatic conditions and vegetation, ranging from $10^{3}$ to $10^{6} \mathrm{CFU} / \mathrm{g}(11)$. Some researchers $(11,12)$ consider them to be free living soil microorganisms, while the others (13), on the contrary, designate these bacteria as a common inhabitant of the rhizosphere, at least in some plants, and B. subtilis and B. megaterim are referred to as the facultative endo- 
phytes $(14,15)$. According to A.I. Melent'ev (16), a survival rate of spore forming bacteria in the rhizosphere of cereals depended on the number, species and strain of introduced microorganisms. Their number on the roots of plants varied from $10^{4}$ to $10^{7} \mathrm{CFU}$ per $1 \mathrm{~g}$ of the roots, being lower by the end of vegetation compared to initial period. Most bacterial cells were transformed to spores which were not physiologically active and thus unable to affect plant growth and development.

As to spore forming aerobic bacteria inoculated into the soil, it is little known about their survival. Poor knowledge results in lack of the approaches to optimization of the inoculation procedure to make the conditions favorable for the bacteria and allow effective application of their preparations for plant growth stimulation and soil bioremediation in environmentally friendly agrotechnologies.

We studied the survival of Bacillus megaterium introduced into the soil and herbicide Promentryn degradation as influenced by different conditions.

Technique. Rifampicine resistant B. megaterium $501^{\text {rif }}$ mutant obtained by gradient selection of resistant forms (17) of parental B. megaterium 501 strain isolated from medium loamy ordinary chernozem (Kokchetav region, Kazakhstan). B. megaterium 501 is deposited in Collection of Agricultural Microorganisms (VKSHM, All Russian Research Institute of Agricultural Microbiology). B. megaterium $501^{\text {rif }}$ was cultivated in Erlenmeyer flasks on a rotary shaker at $140 \mathrm{rpm}$ (UMVT-12-250, Ellion, Russia) using nutrient medium that consists of $(\mathrm{g} / \mathrm{l}): \mathrm{K}_{2} \mathrm{HPO}_{4}-1.6, \mathrm{KH}_{2} \mathrm{PO}_{4}-0.4, \mathrm{NH}_{4} \mathrm{NO}_{3}-0.5, \mathrm{MgSO}_{4}-0.2$, Ca$\mathrm{CO}_{3}-0.025, \mathrm{FeSO}_{4}-0.025$, yeast extract $-0,2$, sucrose -10 , pH 6.8-7.0. Sod-podzolic sandy loam soil $(\mathrm{pH}$ 6.7) was filled into plastic containers and inoculated 2-day liquid culture of $B$. megaterium 501rif, containing not less than $90 \%$ of the living cells. Soil moisture was maintained between 50-60\% of the total capacity.

Effect of temperature was studied at 4,20 и $37^{\circ} \mathrm{C}$. To estimate the influence of organic substances, the chopped oat straw $(0.2 \mathrm{~mm})$ and corn flour were added in an amount of $20 \mathrm{~g}$ per $1 \mathrm{~kg}$ of soil. To examine the effect and degradation rate of Prometryne, the 2-methylthio-4,6-bis(isopropylamino)sym-triazine, $50 \%$ water emulsion of powder herbicide (Panama Agrochemicals Inc., Panama Republica) was added to the soil at 4 and $20 \mathrm{mg} / \mathrm{kg}$.

Total number of B. megaterium 501 rif (CFU/g of soil) was evaluated by serial dilution of bacterial suspension (19) spread onto nutrient media consisting of $(\mathrm{g} / \mathrm{l}): \mathrm{NH}_{4} \mathrm{NO}_{3}-0.5, \mathrm{~K}_{2} \mathrm{HPO}_{4}-1.6, \mathrm{KH}_{2} \mathrm{PO}_{4}-0.4, \mathrm{MgSO}_{4}-0.2$, $\mathrm{CaCO}_{3}-0.025, \mathrm{FeSO}_{4}-0.025$, sucrose -10 , yeast extract $-0,2$, agar -20 , rifampicine $-0,02$. The spores number was assessed in suspensions after their pasteurization at $80{ }^{\circ} \mathrm{C}$ for $10 \mathrm{~min}$.

Prometryn was extracted from soil using acetone method and analyzed by gas-liquid chromatography (GLC) (20).

Statistical analysis was performed at $\mathrm{P}_{0.05}$ level (21).

Results. In nonsterile soil at low temperature (Fig. 1) a sharp decrease of B. megaterium 501rif number was observed after inoculation. The most of bacteria were in the form of vegetative cells. At $4{ }^{\circ} \mathrm{C}$, being lower than growth minimum for B. megaterium 501 rif, the sporulation delayed and therefore most of vegetative cells died. After 1 month the total number of $B$. megaterium $501^{\text {rif }}$ was 1000 times less than at the beginning of the experiment. Activation of Fusarium and Penicillium growth was detected. Therefore, the law temperature shock reduces protective functions and competitiveness of $B$. megaterium.

Relatively high survival of $B$. megaterium $501^{\text {rif }}$ was found at $37{ }^{\circ} \mathrm{C}$. After 32 days the total number of inoculated bacteria in soil decreased 3 times compared to initial level, and the sporulation frequency reached $100 \%$ 
after 12 days.

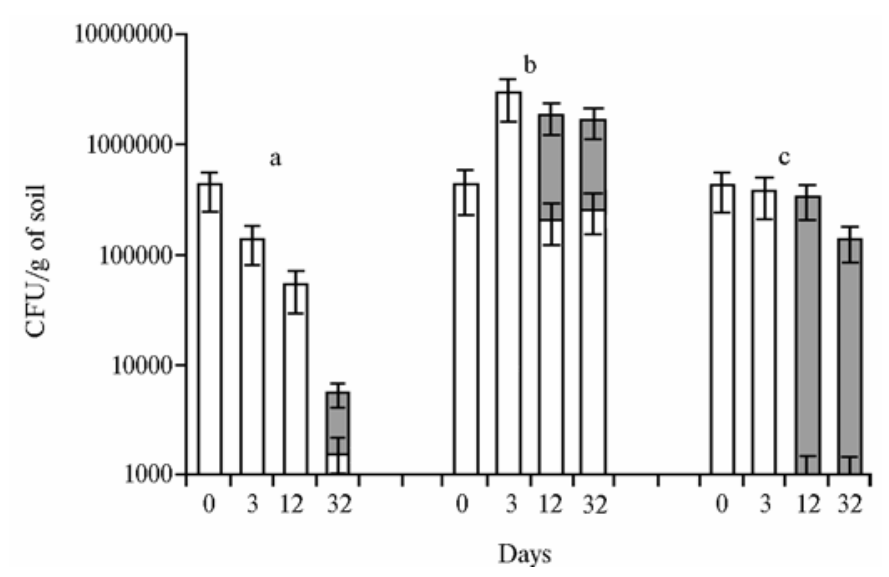

Fig. 1. Dynamics of survival and spore formation in Bacillus megaterium 501 rif after inoculation as related to soil temperature: $a, b$, с $-4,20$ и $37{ }^{\circ} \mathrm{C}$, respectively; grey and white color means spore number and cell number, respectively.

Most favorable conditions for $B$. megaterium 501 if in nonsterile soil were formed at $20{ }^{\circ} \mathrm{C}$. Already 3 days after inoculation the bacteria increased in number almost 10 times and the level remained high until the end of the experiment after 32 days. Sporulation was observed on the day 12 , but the proportion of the spores was less than $30 \%$.

Therefore, in the microbiome of sod-podzolic soil the B. megaterium $501^{\text {rif }}$ remained active for all the time of observation.

When chopped straw added, the number of inoculated B. megaterium

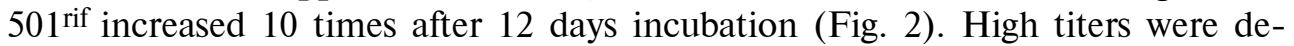
tected during a month, with the number of vegetative cells more than $10^{5}$ $\mathrm{CFU} / \mathrm{g}$. The same was also found when corn flour added. However, in this case there was intensive sporulation, and after a month the number of spore reached $100 \%$.

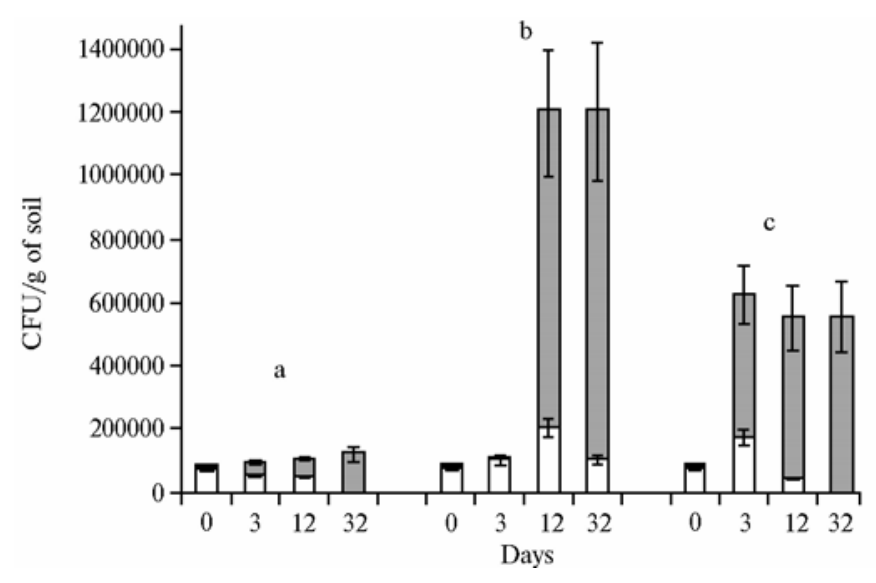

Fig. 2. Dynamics of survival and spore formation in Bacillus megaterium 501rif after inoculation as related to extra organic matter: a, b, c - control, oat straw and corn flour, respectively; grey and white color means spore number and cell number, respectively.
A positive effect of straw and corn flour on B. megaterium $501^{\text {rif }}$ is obviously due to more nutrients in soil promoting more vital activity in the microorganism. Also it could result from positive effect of these substrates on formation of microbe association favorable for B. megaterium.

For several decades the interrelation between microorganisms and xenobiotics is being under consideration. Herbicides are such xenobiotics widely used in agriculture for weed control (18). These chemicals impact on soil microbiomes, and soil fertility in general, also detoxication and degradation of pesticides in nature are considered an urgent problem because many of them are dangerous for the environment, people and animals.

We studied the interrelation between $B$. megaterium $501^{\text {rif }}$ inoculated into the soil and Prometryn, the herbicide widely used for weed control on potato, soybean, carrot and other crops. It was shown that Prometryn applied at the doses dozens times more than those used during commercial crop cultivation did not affect $B$. megaterium $501^{\text {rif }}$, and its number even increased significantly in the 
presence of oat straw (Table).

Dynamics of survival and spore formation (CFU, 103/g) of Bacillus megaterium 501 rif after inoculation into soil as influenced by herbicide Prometryn and oat straw $(X \pm x)$

\begin{tabular}{|c|c|c|c|c|}
\hline \multirow{2}{*}{ Days } & \multirow{2}{*}{ Control } & \multicolumn{3}{|c|}{ Prometryn } \\
\hline & & $4 \mathrm{mg} / \mathrm{kg}$ of soil & $20 \mathrm{mg} / \mathrm{kg}$ of soil & $20 \mathrm{mg} / \mathrm{kg}$ of soil + straw $(2 \%)$ \\
\hline \multirow[t]{2}{*}{0} & $80 \pm 1.2$ & $80 \pm 1.2$ & $80 \pm 1.2$ & $\underline{80 \pm 1.2}$ \\
\hline & $\frac{00 \pm 1.2}{13 \pm 0.5}$ & $\frac{00 \pm 1.2}{13 \pm 0.5}$ & $\frac{00 \pm 1.2}{13 \pm 0.5}$ & $\frac{00 \pm 1.2}{13 \pm 0.5}$ \\
\hline \multirow[t]{2}{*}{3} & $200 \pm 3.4$ & $135 \pm 24.2$ & $90 \pm 6.0$ & $1600 \pm 100.8$ \\
\hline & $150 \pm 12.6$ & $65 \pm 0.9$ & $40 \pm 6.2$ & $500 \pm 8.0$ \\
\hline \multirow[t]{2}{*}{12} & $135 \pm 5.3$ & $114 \pm 3.5$ & $100 \pm 10.0$ & $1200 \pm 150.0$ \\
\hline & $115 \pm 1.5$ & $112 \pm 4.0$ & $54 \pm 2.7$ & $1000 \pm 21.0$ \\
\hline \multirow[t]{2}{*}{32} & $110 \pm 10.7$ & $140 \pm 1.5$ & $118 \pm 9.4$ & $1200 \pm 63.6$ \\
\hline & $90 \pm 2.7$ & $140 \pm 10.3$ & $115 \pm 1.5$ & $1100 \pm 49.5$ \\
\hline
\end{tabular}

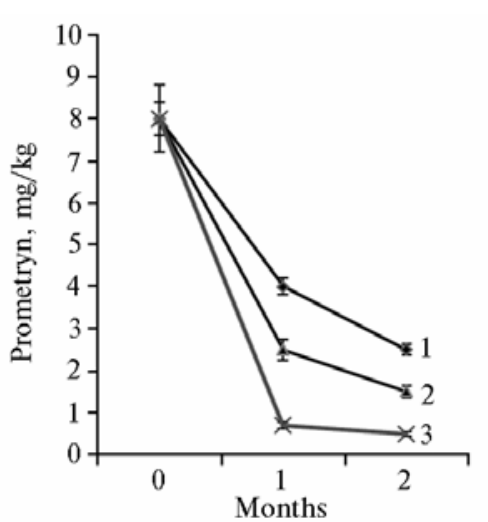

Fig. 3. Dynamics of Prometrine degradation in soil under Bacillus megaterium 501 rif inoculatiuon: $1-$ control, $2-$ inoculation, 3 - inoculation in the presence of oat straw (2\%).

In the soil inoculated with $B$. megaterium $501^{\text {rif }}$ the rate of Prometryn degradation increased significantly (Fig. 3). Most active degradation was observed when we added the oat straw. A month after inoculation the concentration of herbicide was 10 times lower if compared to control, thus correlating with an increase of the total $B$. megaterium $501^{\text {rif }}$ number.

These results lead to the conclusion that applying organic matter, particularly the plant residues enriched with cellulose, and the inoculation with microorganisms capable to degrade the herbicide, are essential and probably the main conditions for improving bioremediation under soil pollution with Prometryn.

So, it is shown that vegetative cells of Bacillus megaterium 501 rif inoculated into soil remain physiologically active for rather long time. When organic matter, such as cereal straw or corn flour, is added, it results in a rapid bacterial growth. Their number increases hundreds times, being kept stable. Active sporulation starts 12 days after the inoculation. The result of introduction and physiological state of the bacteria depend directly on soil temperature. The most favorable temperature for B. megaterium survival, provided optimal moisture, varies from 20 to $37^{\circ} \mathrm{C}$. Organic matter enriched with cellulose, such as the chopped straw, crop residues, etc., also contribute to the survival of bacteria. The isolated strain B. megaterium $501^{\text {rif }}$ significantly accelerates the Prometryn degradation and can be useful in biotechnological remediation of soils polluted with this herbicide.

\section{REFERENCES}

1. Tikhonovich I.A., Kozhemyakov A.P., Chebotar' V.K., Kruglov Yu.V., Ka n d y b in N.V., La p te v G.Yu. Biopreparaty $v$ sel'skom khozyaistve. Metodologiya i praktika primeneniya mikroorganizmov v rastenievodstve $i$ kormoproizvodstve [Biopreparations in agriculture. Methodology and practical use of microorganisms in crop and forage production]. Moscow, 2005.

2. $\quad \mathrm{Z}$ a val in A.A. Biopreparaty, udobreniya $i$ urozhai [Biopreparations, fertilizers and yield production]. Moscow, 2005.

3. B a s ha n Y. Inoculants of plant growth-promoting bacteria for use in agriculture. Biotechnology Advances, 1998, 16(4): 729-770 (doi: 10.1016/S0734-9750(98)00003-2).

4. Mostafiz S.B., Rahman M., Rah man M. Biotechnology: role of microbes in sustainable agriculture and environmental health. The Internet Journal of Microbiology, 2012, 10(1) (http://ispub.com/IJMB).

5. Kandybin N.V., Patyka T.I., Ermolova V.P., Patyka V.F. Mikrobiokontrol' 
chislennosti nasekomykh i ego dominanta Bacillus thuringiensis. [Microbiocontrol of insects and Bacillus thuringiensis as its dominant]. St. Petersburg, 2009.

6. Sanahuja G., Banakar R., Twyman R.M., Cape 11 T., Christou P. Bacillus thuringiensis: a century of research, development and commercial applications. Plant Biotechnol. J., 2011, 9(3): 283-300 (doi: 10.1111/j.1467-7652.2011.00595.x).

7. Chebotar' V.K., Z a vali in A.A., K i prushkina E.I. Effektivnost' primeneniya preparata ekstrasol [Efficacy of Extrasol application]. Moscow, 2007.

8. O m e r A.M., Bioformulations of Bacillus Spores for using as biofertilizer. Life Sci. J., 2010, 7(4): 124-131.

9. Chumthong A., Kanjanamaneesathian M., Pengnoo A., Wiwattana$\mathrm{p}$ a t a p e R. Water-soluble granules containing Bacillus megaterium for biological control of rice sheath blight: formulation, bacterial viability and efficacy testing. World Journal of Microbiology and Biotechnology, 2008, 24(11): 2499-2506 (doi: 10.1007/s11274-008-9774-7).

10. Zlotnikov A.K., Alekhin V.T., Andrianov A.D. et al. Biopreparat al'bit dlya povysheniya urozhaya $i$ zashchity rastenii: opyty, rekomendatsii, rezul'taty primeneniya /Pod redaktsiei V.G. Mineeva [Albit for yield increase and plant protection: experience, recommendations and results of application. V.G. Mineev (ed.)]. Moscow, 2008.

11. Mishustin E.N., Mirzoeva V.A. Izvestiya AN SSSR, Seriya biologicheskaya, 1965, 5: 682-691.

12. B e a t ti e G.A. Plant associated bacteria: survey, molecular phylogeny, genomics and recent advances. In: Plant associated bacteria /S.S. Gnanamanickam (ed.). Springer, Dordrecht, Netherland, 2007: 1-56.

13. Mille r H.J., H e n re $n$ G., V a n Ve e n L.F. Variation and composition of bacterial populations in the rhizospheres of maize, wheat and grass cultivars. Can. J. Microbiol., 1989, 35(46): 656-660 (doi: 10.1139/m89-106).

14. Rosenblueth M., Martinez-Romero E. Bacterial endophytes and their interactions with hosts. Mol. Plant Microbe Interact., 2006, 19: 827-837 (doi: 10.1094/MPMI-19-0827).

15. Figueiredol J., Gomes E., Guimarres C., Gomes de Paula Lana S.U., Teixe ira M, Lima G., B ress a n W. Molecular analysis of endophytic bacteria from the genus Bacillus isolated from tropical maize (Zea mays L.). Braz. J. Microbiol., 2009, 40(3): 522-534 (doi: 10.1590/S1517-83822009000300014).

16. Melent'ev A.I. Aerobnye sporoobrazuyushchie bakterii Bacillus Chon. $v$ agroekosistemakh [Aerobic sporeforming bacteria Bacillus Chon. in agroecosystems]. Moscow, 2007.

17. Metody obshchei bakteriologii /Pod redaktsiei F. Gerkharda [Methods of general bacteriology. V. 2. F. Gerhard (ed.)]. Moscow, 1983, tom 2.

18. Mel'nikov N.N., Novozhilov K.V., Belan S.R., Pylova T.N. Spravochnik po pestitsidam [Pesticide manual]. Moscow, 1985.

19. Metody pochvennoi mikrobiologii i biokhimii /Pod redaktsiei D.G. Zvyagintseva [Methods of soil microbiology and biochemistry. D.G. Zvyagintsev (ed.)]. Moscow, 1991.

20. Metody opredeleniya mikrokolichestv pestitsidov v produktakh pitaniya, kormakh i vneshnei srede /Pod redaktsiei M.A. Klisenko [Methods for determination of trace pesticides in food, feed and the environment. M.A. Klisenko (ed.)]. Moscow, 1983.

21. Plok hinski i N.A. Biometriya [Biometry]. Moscow, 1970. 